\title{
ANALYSIS OF ADJECTIVES IN HEADLINE NEWS ONLINE
}

\section{Hermariyanti Kusumadewi; Ferawaty Puspitorini}

\author{
Program of English Education, Faculty of Language and Art, University of Indraprasta PGRI \\ Jalan Nangka No. 58C Tanjung Barat, Jagakarsa, South Jakarta 12530 \\ hermariyanti@gmail.com, feraliang06@gmail.com
}

\begin{abstract}
The purpose of this study is to analyze the adjectives in headline news online; to answer questions such as: How many adjectives that can be found in headline news online? What kind of adjectives that are widely used in headline news online? The data in this study were collected from headline news online. Literature review and relevant research has been observed to obtain a description of the data, in this case headline news online. The results showed that the author of the article using different types of adjectives, the adjectives most often used is a descriptive adjective. The main reason of the research on the analysis of adjectives in headline news online is to provide information on headline news online that can be read on the internet, and provide benefits in the study of language.
\end{abstract}

Key words: adjective, headline news online, reading habit

\begin{abstract}
ABSTRAK
Tujuan dari penelitian ini adalah untuk menganalisis kata sifat dalam headline news online; untuk menjawab pertanyaan seperti: Berapa banyak kata sifat yang dapat ditemukan di headline news online? Apa jenis kata sifat yang banyak digunakan dalam Headline News online? Data dalam penelitian ini dikumpulkan dari headline news online. Kajian literatur dan penelitian yang relevan telah diamati untuk memperoleh gambaran dari data, dalam hal ini headline news online. Hasil penelitian menunjukkan bahwa penulis artikel menggunakan berbagai jenis kata sifat, kata sifat yang paling sering digunakan adalah kata sifat deskriptif. Alasan utama dari penelitian tentang analisis kata sifat dalam headline news online adalah untuk memberikan informasi tentang headline news online yang dapat dibaca di internet, dan memberikan manfaat dalam studi bahasa.
\end{abstract}

Kata kunci: kata sifat, berita utama online, kebiasaan membaca 


\section{INTRODUCTION}

Many of you may think that reading is a boring activity. Well, traditional reading, what I mean in here is reading text books can be a boring activity. But when we develop the understanding that reading is not only to read the book but also to read anything which has articles and paragraphs and also have stories to be told is what we called reading too. Then, when we get this understanding, reading will become an exciting activity, yet it will develop our reading habit.

For most Indonesians, reading habit is not one of the important things in their life, this activity is really far of being a habit. As I learned from modern countries, the society loves reading. Reading is a habit for them. What I want to tell in here is as Indonesian, we can learn that from reading we can get many information that we need. We can read many things from books, newspapers, magazines, to online articles that can be acsess easily therefore we can grow this activity to be a good habit.

There are many types of article that can be read. In this globalized era, it is easy to find articles from the internet. We can also easily get the softcopy of the books for free, yap for free. Internet supplies many things that we need, especially for reading any articles that we need. There are many information that we can get from online news, we can get it easily as long as there is internet connection.

In reading news, we have to understand such words that is used in order to avoid misinterpretation. As we know when we learn grammar, sentence pattern plays main role to make a good understanding to the sentence. We have to know the noun, verb, adjective, adverb, preposition in the sentences therefore we can understand what the sentence talks about. In this case, when we read headline news online, we have to know what sentence patterns that stress out there to get the point of the news aesily.

English plays as a foreign language in Indonesia which makes Indonesian only has a little willing to read articles in English. But, we know that today since they can not be separated from the internet, they must be familiar with English. Related to numerous studies, one of them has been done by Maria Carolina Jenssen (2010) entitled "A Framing Analysis of Webblogs and Online Newspaper". The study examined possible differences in framing of information in news weblogs and professional news articles. The articles showed differences in framing. However, the results of the study indicated that differences in framing of information are not related to the publication type (online newspaper or weblog) but are merely incidental.

Related to this topic, it can be inferred that several studies related to the issue of online newspaper it means that we live in the era of technology in which we can get a lot of information from online sources. The focus in here is, when we know the sentence pattern used in the news, headline news, it may be easily for us to get the main point to be discussed. Related to such problems I write above, in this research I want to analyze the adjectives in headline news online. Therefore the aims of the research are To know how many adjectives that we can find in headline news online. To know what type of adjectives that we can find in Headline News Online.

An online newspaper is the online version of a newspaper, either as a stand-alone publication or as the online version of a printed periodical. Going online created more opportunities for 
newspapers, such as competing with broadcast journalism in presenting breaking news in a more timely manner. The credibility and strong brand recognition of well-established newspapers, and the close relationships they have with advertisers, are also seen by many in the newspaper industry as strengthening their chances of survival. The movement away from the printing process can also help decrease costs.

Sajib stated eight (8) important things of reading newspaper in online: While someone is reading a newspaper he or she is cutting a tree. Nowadays the importance of online newspaper has tremendous value. People are becoming more accustomed and used to with this type of newspapers. It has various positive aspects.

One of the most important components of a sentence is the adjective. This part of speech is so common that people use it almost automatically, both in speech and in writing. On the internet site http://www.thefreedictionary.com/adjec tive here is the meaning of adjective: The part of speech that modifies a noun or other substantive by limiting, qualifying, or specifying and distinguished in English morphologically by one of several suffixes, such as -able, -ous, -er, and est, or syntactically by position directly preceding a noun or nominal phrase.

An adjective is a part of speech which describes, identifies, or quantifies a noun or a pronoun. So basically, the main function of an adjective is to modify a noun or a pronoun so that it will become more specific and interesting. Instead of just one word, a group of words with a subject and a verb, can also function as an adjective. When this happens, the group of words is called an adjective clause.
There are types of adjectives, namely: 1) descriptive adjectives. Descriptive adjectives simply say something about the quality or the kind of the noun or pronoun they're referring to. Examples: She is tired, Adrian's reflexes are amazing; 2) adjectives of number or adjectives of quantity. As the name suggests, this kind of adjective answers the question, "How many?" or "How much?" Examples: Twenty-two students failed the exam, The plants need more water; 3) demonstrative adjectives. Demonstrative adjectives point out pronouns and nouns, and always come before the words they are referring to. Examples: I used to buy this kind of shoes, When the old man tripped over that wire, he dropped a whole bag of groceries. 4) possessive adjectives. Obviously, this kind of adjectives shows ownership or possession. Aside from that, possessive adjectives always come before the noun. Examples: I can't answer my seatwork because I don't have a calculator, Trisha sold his dog. 5) interrogative adjectives. Interrogative adjectives ask questions and are always followed by a noun. Examples: What movie are you watching? Which plants should be placed over here?; 6) degrees of adjectives. There are only three degrees or levels of adjectives (also known as degrees of comparison) namely, positive, comparative, and superlative. When you talk about or describe only a single person, place, or thing, you should use the positive degree. Examples: She is a beautiful lady, It was a memorable trip.

The literature on newspaper headlines covers a wide range of theoretical and empirical topics, all the way from the grammar of English headlines to the effects of headlines on news comprehension and recall. Surprisingly, however, the literature 
dealing directly with the communicative function of headlines is rather sparse.

"News is a representation of the world in language" (Fowler in Šipošová, 2011:11). Another source, LDCE, defines news as reports of recent events in the newspapers or on the radio or television which narrows down the definition to an information about recent events that are of interest to a sufficiently large group, or that may affect the lives of a sufficiently large group, i.e., not everything that happens at the moment around us qualifies as news. Therefore, only some events are "worth" being spread around and presented as news to people around the globe. News is therefore a process of selection i.e., there are people that are responsible for what will and will not be included in news. For this reason, the process of selection creates a room for bias. What also affects the impartiality of news, are the institutions that own the individual media. Another instrument to skew the reality of news is the language itself. It is a powerful tool that can be easily abused to manipulate the public opinion.

Headlines belong to the linguistic area that arouses interest not only in scholars but also common people since their function is to attract. "Their function in newspapers is therefore very important. However, not so much attention, if any at all, has been paid to the study of sub headlines" (Šipošová, 2011:10). Therefore, the language of this type of newspaper will differ from the one used in serious press.

Related to numerous studies in the cases of analysis of online news, one of them has been done by Maria Carolina Jenssen (2010) entitled "A Framing Analysis of Webblogs and Online Newspaper". The study examined possible differences in framing of information in news weblogs and professional news articles. A frame analysis was conducted to answer the main question: Is news framed differently in online newspapers as compared to weblogs? Articles from four blogs and four online newspapers were gathered over a period of 30 days. A total of 43 frames were identified in the selected blogs whereas 92 frames were identified in the selected online newspapers. The most commonly identified frame in both blogs and on line newspapers was the progress frame with 51 appearances. The justice frame was used least. The articles showed differences in framing. However, the results of the study indicated that differences in framing of information are not related to the publication type (online newspaper or weblog) but are merely incidental. According to this study, framing cannot be used as an indicator for possible differences in the production and publication of news articles in weblogs and online newspapers.

Saulè Petronienè, Indrè Žvirblytè (2012) entitled "Headlines of Online News Articles: Degree of Equivalence in Translation". They found that online news articles are characterized by publicist style and the main features of it are accuracy and clarity. Headlines are the most important part of online news articles, they have to capture readers' attention, intrigue and at the same time provide the reader with a considerable amount of information. The results of the analysis demonstrate that the majority of the headlines are of partial equivalence which, therefore, constitutes $80 \%$ ( $48 \%$ of the headlines are of near-optimum translation and $32 \%$ of the headlines are of weak translation) out of one hundred analyzed headlines; whereas the minority of the headlines are of optimum (8\%) and zero $(12 \%)$ translation. Thus, the analysis 
has revealed that in order to make a more comprehensive study of media language (headlines in particular), there is a need to analyze not only the headlines, but the articles as well. The purpose of this study was to analyze the adjectives in headline news online; to answer questions such as: How many adjectives that can be found in headline news online? What kind of adjectives that are widely used in headline news online?

\section{METHOD}

This research is conducted qualitative method descriptively. Descriptive research, according to Gay and Airasian (2000:275) is "a study to determine and describe the way things are". The data are collected from headline news online. Literature review and relevant research have been observed to obtain the data description. In this case, the headlines will be employed. It aims is not to analisis and explain about the intrinsic element in a headline news online. Here, based on the headline news online, after analyzing the online news, the next following steps as a part of data analysis. They are: choosing headline news online and analysing headline news online by writing and listing the adjectives that find in the headline news online.

The primary data of the research is the headline news online. There are 20 headlines to be analyzed. The data presented of this research taken from The Jakarta Post online newspaper. The sources of the data are taken from the Jakarta Post Online newspaper from September 2015 - January 2016 articles. Secondary data is the support data of the research. In analysing the adjectives in headline news online the researchers use the secondary data from some sources such as Thesaurus dictionary, internet and literature books. Those sources are very useful in order give more information of the adjectives use in headline news online.

This research conducted qualitative method descriptively. The researchers did some steps in data collection. There are 20 articles to be analyzed.

Table1. Classifying the Headlines Blue Print

Instrument

\begin{tabular}{c|c|c|c|c|c|c|c|}
\hline $\begin{array}{c}\text { Headline } \\
\text { News } \\
\text { Online }\end{array}$ & \multirow{2}{*}{ Adj } & \multicolumn{6}{|c|}{ Types } \\
\cline { 3 - 7 } & De & Quan & Dem & Pos & Int & Deg \\
\hline & & & & & & & \\
\hline & & & & & & & \\
\hline
\end{tabular}

Information:

De : Descriptive adjective

Quan : Adjective of Quantity

Dem : Demonstrative adjective

Pos : Possesive adjective

Int : Interrogative adjective

Deg : Degrees of adjective

\section{RESULTS AND DISCUSSION}

Based on the source of data, the researchers analyze the both primer data and secondary data. The primer data takes from the headline news online and secondary data takes from each of the articles. After listing all the articles which taken from Jakarta Post online newspaper, the researchers try to find the adjectives in each of the articles. There are 20 articles in as follow. 
Table 2. List of Headline News Online from the Jakarta Post Online Newspaper

\begin{tabular}{|c|l|}
\hline No & \multicolumn{1}{|c|}{ Title } \\
\hline 1. & 60 Percent of Jakarta's Sidewalks Demaged \\
\hline 2. & $\begin{array}{l}\text { After Beijing, Tianjin and Four Heibei Cities } \\
\text { issues Red Alert }\end{array}$ \\
\hline 3. & $\begin{array}{l}\text { Alvin and The Chipmunks: The Road Chip: } \\
\text { The Mischievious gang goes on Crazy } \\
\text { Adventures }\end{array}$ \\
\hline 4. & $\begin{array}{l}\text { Awaiting Broadband Revolutionary in the } \\
\text { "Hippo Country" }\end{array}$ \\
\hline 5. & $\begin{array}{l}\text { College Begins Effort to Fire Professor for } \\
\text { Comment on Islam }\end{array}$ \\
\hline 6. & $\begin{array}{l}\text { Study: Ebola Survivors' Blood didn't Help } \\
\text { Patients in Guinea }\end{array}$ \\
\hline 7. & $\begin{array}{l}\text { Facebook Working on Long-Sought 'dislike' } \\
\text { Button }\end{array}$ \\
\hline 8. & Editorial: Golkar in the Dark \\
\hline 9. & $\begin{array}{l}\text { How Baoding City in Hebei Copes with } \\
\text { Month-long alert for Smog }\end{array}$ \\
\hline 10. & $\begin{array}{l}\text { News Analysis: Jokowi, Obama put Smile on } \\
\text { Second-rate Relationship }\end{array}$ \\
\hline 11. & $\begin{array}{l}\text { Murakami's Aged Men Showed Japan's Post } \\
\text { Disaster Spirituality }\end{array}$ \\
\hline 12. & New Fair Opens Door to Asian Art Collectors \\
\hline 13. & Ngenest - A Mix of Laugh, Tears \\
\hline 14. & Shakespeare Lives in Our Language, Society \\
\hline 15. & Snowden Bust Kicks of New York Art Festival \\
\hline 16. & $\begin{array}{l}\text { Slacklining: an Extreme Sport that the Non- } \\
\text { Sporty Can Do }\end{array}$ \\
\hline 17. & $\begin{array}{l}\text { Star Wars' becomes Highes Grossing } \\
\text { Domestic Movie Ever }\end{array}$ \\
\hline 18. & $\begin{array}{l}\text { New Analysis: The 'Dalang' makes a Twist in } \\
\text { Political Shadow Play }\end{array}$ \\
\hline 19. & $\begin{array}{l}\text { The Year in Music 2015: Plenty of Great } \\
\text { Things }\end{array}$ \\
\hline 20. & $\begin{array}{l}\text { A Glimpse of Upper-Class Life Style in the } \\
\text { Early Days of Modern Korea }\end{array}$ \\
\hline
\end{tabular}

From 20 of headline news online, the researchers will analyze the adjectives that can be found in each article. Based on the source of data, the researchers analyze the both primer data and secondary data. The primer data takes from the headline news online and secondary data takes from each of the articles. After listing all the articles which taken from Jakarta Post online newspaper, the researchers try to find the adjectives in each of the articles. Here are the findings summary. 
Table 3. Findings

\begin{tabular}{|c|c|c|}
\hline $\mathbf{N O}$ & Title & Adjectives \\
\hline 1 & $\begin{array}{l}60 \text { Percent of Jakarta's Sidewalks } \\
\text { Demaged }\end{array}$ & Most, Damaged, this, Irres ponsible, and more. \\
\hline 2 & $\begin{array}{l}\text { After Beijing, Tianjin and Four Heibei } \\
\text { Cities is sues Red Alert }\end{array}$ & Highest, Bad, More, Cautious, Stricter. \\
\hline 3 & $\begin{array}{l}\text { Alvin and The Chipmunks: The Road } \\
\text { Chip: The Mischievious gang goes on } \\
\text { Crazy Adventures }\end{array}$ & $\begin{array}{l}\text { Adoptive, Mischievous, High-pitched, Old, } \\
\text { Tedious, Spectacle, chubby. }\end{array}$ \\
\hline 4 & $\begin{array}{l}\text { Awaiting Broadband Revolutionary in } \\
\text { the "Hippo Country" }\end{array}$ & $\begin{array}{l}\text { Latest, Most, Unwilling, Imperative, Worse, War- } \\
\text { torn. }\end{array}$ \\
\hline 5 & $\begin{array}{l}\text { College Begins Effort to Fire } \\
\text { Professor for Comment on Is lam }\end{array}$ & their differences, evangelical, and those efforts. \\
\hline 6 & $\begin{array}{l}\text { Study: Ebola Survivors' Blood didn't } \\
\text { Help Patients in Guinea }\end{array}$ & licensed, devastating, more dramatic, better effect. \\
\hline 7 & $\begin{array}{l}\text { Facebook Working on Long-Sought } \\
\text { 'dislike' Button }\end{array}$ & $\begin{array}{l}\text { oft-repeated, special, awkward, better way, more } \\
\text { broadly. }\end{array}$ \\
\hline 8 & Editorial: Golkar in the Dark & $\begin{array}{l}\text { Oldest, Second-largest, Warring camps, Winning, } \\
\text { Simultaneous, Unthinkable, Critical, Well- } \\
\text { established, Ugly fact, Bitter fight, Reconciliatory. }\end{array}$ \\
\hline 9 & $\begin{array}{l}\text { How Baoding City in Hebei Copes } \\
\text { with Month-long alert for Smog }\end{array}$ & $\begin{array}{l}\text { Larger-than-usual, Small, Thick, Injurious smog, } \\
\text { Happy, Hard-hitting. }\end{array}$ \\
\hline 10 & $\begin{array}{l}\text { News Analysis: Jokowi, Obama put } \\
\text { Smile on Second-rate Relationship }\end{array}$ & $\begin{array}{l}\text { Big deal, Star-power, Nice words, Those smiles, } \\
\text { Second-rate, Lukewarm, Third-largest, Inopportune } \\
\text { time, improbable. }\end{array}$ \\
\hline 11 & $\begin{array}{l}\text { Murakami's Aged Men } \text { Showed } \\
\text { Japan's Post Disaster Spirituality }\end{array}$ & $\begin{array}{l}\text { Grotesque, Colorful, Spiritual, Uncompromising, } \\
\text { Old, Retrospective, Toothless grins, Bald, } \\
\text { Wrinkled, Wierd. }\end{array}$ \\
\hline 12 & $\begin{array}{l}\text { New Fair Opens Door to Asian Art } \\
\text { Collectors }\end{array}$ & $\begin{array}{l}\text { Contemporary, New, Vibrant, Top, Middle, upper- } \\
\text { middle, ambitious, flourishing, Affordable, Highest, } \\
\text { Young, Discretionary. }\end{array}$ \\
\hline 13 & Ngenest - A Mix of Laugh, Tears & $\begin{array}{l}\text { Grim, Different, Lighter, Pathetic, Funny, } \\
\text { pioneering comedians, solid story, romantic. }\end{array}$ \\
\hline 14 & $\begin{array}{l}\text { Shakespeare Lives in Our Language, } \\
\text { Society }\end{array}$ & $\begin{array}{l}\text { Greatest, Extraordinary, Narrow, critical role, } \\
\text { motionless, innovative, jealous, longest. }\end{array}$ \\
\hline 15 & $\begin{array}{l}\text { Snowden Bust Kicks of New York Art } \\
\text { Festival }\end{array}$ & Guarded, Safe, Small, Empty, Angry, Coolest. \\
\hline 16 & $\begin{array}{l}\text { Slacklining: an Extreme Sport that } \\
\text { the Non-Sporty Can Do }\end{array}$ & $\begin{array}{l}\text { Dramatic, Heady, Extreme, Narrow, Dynamic, } \\
\text { Bouncy, Different, Closest. }\end{array}$ \\
\hline 17 & $\begin{array}{l}\text { 'Star Wars' becomes Highes Grossing } \\
\text { Domestic Movie Ever }\end{array}$ & shy and significant. \\
\hline 18 & $\begin{array}{l}\text { New Analysis: The 'Dalang' makes a } \\
\text { Twist in Political Shadow Play }\end{array}$ & $\begin{array}{l}\text { Predictable, Faithful, Unexpected, Largest, Good, } \\
\text { Closest, Diminutive, Competent, Trusted. }\end{array}$ \\
\hline 19 & $\begin{array}{l}\text { The Year in Music 2015: Plenty of } \\
\text { Great Things }\end{array}$ & $\begin{array}{l}\text { Clear, Plenty of, Great, Intellectual, Creative, } \\
\text { Elected, Abuzz, Illegal. Plenty of is adjective of } \\
\text { quantity. }\end{array}$ \\
\hline 20 & $\begin{array}{l}\text { A Glimpse of Upper-Class Life Style } \\
\text { in the Early Days of Modern Korea }\end{array}$ & High-rise, first, wealthiest, upper-class, modern. \\
\hline
\end{tabular}

Headline 1, there are five adjectives in this headline news, the adjectives are: most, damaged, this, irresponsible, and more. Most is a superlative adjective, damaged is descriptive adjective, this (followed by year) is a demonstrative adjective, and more is comparative adjective.

Headline 2, there are five adjectives in this online headlinenews, the adjectives are: highest, bad, more, cautious, and stricter. Highest is a superlative adjective, bad is descriptive 
adjective, more is a comparative adjective, cautious is a demontrative adjective, and stricter is a comparative adjective.

Headline 3, there are seven adjectives in this online headline news, the adjectives are: adoptive, mischievous, high-pitched, old, tedious, spectacle, and chubby. These words are demonstrative adjective.

Headline 4, there are six adjectives in this online headline news, the adjectives are: latest, most, unwilling, imperative, worse, and wartorn. Latest and most are superlative adjective, unwilling, imperative, worse, and war-torn are demontrative adjective.

Headline 5, there are three adjectives in this online headline news, the adjectives are: their differences, evangelical, and those efforts. Their differences are demonstrative adjective. Evangelical is descriptive adjective. Those efforts is demonstrative adjective.

Headline 6, there are four adjectives in this online headline news, the adjectives are: licensed, devastating, more dramatic, and better effect. Licensed and devastating are descriptive adjective. More dramatic and better effect are comparative adjective.

Headline 7, there are five adjectives in this online headline news, the adjectives are: oft-repeated, special, awkward, better way, and more broadly. Oft-repeated, special, and awkward are descriptive adjective. Better way and more broadly are comparative adjective.

Headline 8, there are eleven adjectives in this online headline news, the adjectives are: oldest, secondlargest, warring camps, winning, simultaneous, unthinkable, critical, well-established, ugly fact, bitter fight, and reconciliatory. Oldest is a superlative adjective. Second largest is adjective of quantity. Warring camps, winning, simultaneous, unthinkable, critical, well-established, ugly fact, bitter fight, and reconciliatory are descriptive adjective.

Headline 9, there are six adjectives in this online headline news, the adjectives are: larger-than-usual, small, thick, injurious smog, happy, and hard-hitting. Larger-than-usual is comparative adjective. Small, thick, injurious smog, happy, and hard-hitting are descriptive adjective.

Headline 10, there are nine adjectives in this online headline news, the adjectives are: big deal, star-power, nice words, those smiles, second-rate, lukewarm, third-largest, inopportune time, improbable. Big deal, star-power, nice words, lukewarm, inopportune time, and improbable are descriptive adjective. Second-rate and third largest are quantity of adjective.

Headline 11, there are eleven adjectives in this online headline news, the adjectives are: grotesque, colorful, spiritual, uncompromising, old, retrospective, toothless grins, bald, wrinkled, wierd. grotesque, colorful, spiritual, uncompromising, old, retrospective, toothless grins, bald, wrinkled, and wierd are descriptive adjective.

Headline 12, there are twelve adjectives in this online headline news, the adjectives are: contemporary, new, vibrant, top, middle, upper-middle, ambitious, flourishing, affordable, highest, young, discretionary. Contemporary, new, vibrant, top, middle, upper-middle, ambitious, flourishing, affordable, young, and discretionary are descriptive adjective. Highest is superlative adjective.

Headline 13, there are eight adjectives in this online headline news, the adjectives are: grim, different, lighter, pathetic, funny, pioneering 
comedians, solid story, and romantic. Grim, different, pathetic, funny, pioneering comedians, solid story, romantic is descriptive adjective. Lighter is comparative adjective.

Headline 14, there are eight adjectives in this online headline news, the adjectives are: greatest, extraordinary, narrow, critical role, motionless, innovative, jealous, and longest. Extraordinary, narrow, critical role, motionless, innovative, and jealous, are descriptive adjective. Greatest and longest are superlative adjective.

Headline 15, there are six adjectives which found in the online headline news, the adjectives are: guarded, safe, small, empty, angry, and coolest. Guarded, safe, small, empty, and angry are descriptive adjective. Coolest is superlative adjective.

Headline 16, there are six adjectives in this online headline news, the adjectives are: dramatic, heady, extreme, narrow, dynamic, bouncy, different, and closest. Dramatic, heady, extreme, narrow, dynamic, and bouncy are descriptive adjective. Closest is superlative adjective.

Headline 17, there are two adjectives in this online headline news, the adjectives are: shy and significant. Shy and significant are descriptive adjectives.

Headline 18, there are nine adjectives in this online headline news, the adjectives are: predictable, faithful, unexpected, largest, good, closest, diminutive, competent, and trusted. Predictable, good, faithful, unexpected, diminutive, competent, and trusted are descriptive adjectives. Largest and closest are superlative adjectives.

Headline 19, there are eight adjectives in this online headline news, the adjectives are: clear, plenty of, great, intellectual, creative, elected, abuzz, and illegal. Plenty of is adjective of quantity. Clear, great, intellectual, creative, elected, abuzz, and illegal are descriptive adjective.

Headline 20, there are five adjectives in this online headline news, the adjectives are: high-rise, first, wealthiest, upper-class, and modern. High-rise, first, wealthiest, upper-class, and modern are descriptive adjective. Wealthiest is superlative adjective.

From twenty articles which had been analyzed, writers of the articles use various types of adjectives. The most frequent used of adjective is descriptive adjective and follow by degrees of adjective. This research investigated all the adjectives in headline news online. 20 online articles which have been analyzed are taken from the Jakarta Post. It can be seen that the writer of each articles are using adjectives in several ways to make the articles clear enough, therefore readers will not be puzzled to get the point of the news. By analysing adjectives in headline news online, it can be concluded that adjectives play significant role to build a sentence.

\section{CONCLUSION}

Related to the findings, As the research has mentioned that the objective of this research is to find out the adjectives in headline news online. Therefore, this research limited only to the adjectives in headline news online. For researcher, this could be a basic research which can be followed up to the upcoming one, in which the areas to be researched will be more details in literature field. As the analysis shows that finding the adjectives in headline news online can give important information about going to emphasize the point of the news therefore it avoids misinterpretation from the readers. 


\section{REFERENCES}

Ahmed, M.F. (2002). The Perlocutionary Effect of Speech Acts in Quranic Legal Provisions in Existing English Translations of the Quran. Baghdad: Al Mustinsiriya University.

Bitinienè, A. (2007). Publicistinis Stilius. Vilnius: Vilniaus pedagoginio universiteto leidykla.

Craig, R. (2004). Online Journalism: Reporting, Writing and Editing for New Media. Belmont: Thomson Wadsworth.

Gay, L. R., \& Airasian, P. (2000). Educational Research: Competencies for Analysis and Application. New Jersey: Prentice-Hall.
McNair, B. (2009). News and Journalism in the UK. New York: Taylor \& Francis.

Marcinkevičienè, R. (2008). Žanro ribos ir paribiai. Spaudos patirtys. Vilnius: Versus aureaus.

Rich, C. (2010). Writing \& Reporting News: A Coaching Method. Wadsworth: Cengage Learning.

Šipošová, Alena. 2011. Headlines and Subheadlines: Tense, Modality and Register based on Discourse Analysis of the British Tabloid The Sun. Masaryk University: Faculty of Arts: Department of English and American Studies. English Language and Literature. 